T性 $\beta, c=$ 一定。 $\beta=6.982 \times 10^{-2}, c=7.435 \times 10^{-2}$

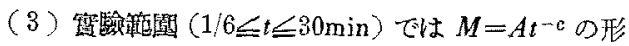

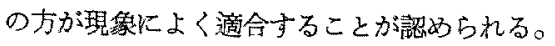

（4）モーメン卜扡䌅比として $A=M_{1}(1 \mathrm{~min})$ 基潅 にすれば

$M / M_{1}=1-\beta \log t$ 或いは $M / M_{1}=t^{-c}$

(賽際は $\alpha-\beta \log t, \alpha^{\prime} t^{-c} て ゙ \alpha, \alpha^{\prime}=1$ となる。) 回復

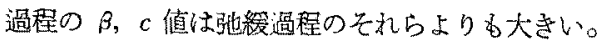

(5) $T$ 及び $t$ の函數としてのモーメントは弛編曲面 或い恃等時曲線に表わされる。

この砰究は羣馬大學（工）緎維工菜研究所で行い，

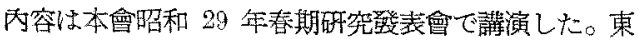

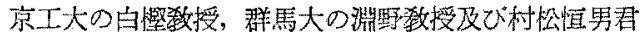
に感謝子る。

$$
\text { 文献 }
$$

1)大濢: 本誌, 9, 36 (颃 28-1)

2) $"$ : " , 9, 173 (昭28-4)

3) " : " , 10, 352(昭29-8)

4)白樫价：維維工業學會誌，8，443(昭17-7)

5) W.G. Hammerle, D.J. Montgomery; Text. Res. J., 23, 595 (1953)

6) 大浱：本誌，9，246(昭28-5)

7) " : ", 10, 116(昭29-3)

\title{
カ一ドのさら發生について
}

\author{
明和紡續株式會社 早川鼠雄・石川 勳・小坂芳樹
}

\section{ON THE THICKNESS VARIATION IN SLIVERS CAUSED BY CARDING}

By Kameo Hayakawa, Isao Ishikawa and Yoshiki Ogawa

On the cotton flat card, the relation between the thickness variations in fed laps and produced slivers has been experimentally studied in the following manners: (1) The method of uniform feeding by laying one handred carded slivers in parallel with the whole width of the card and feeding them into the feed roller. (2) By feeding laps with variation in thickness as shown in Fig. 1, caused by adding proper length and numbers of carded slivers on the former uniform feeding.

After the measurements of thickness variations in the produced slivers on these cases, it may be concluded that the carding engine with adequate settings does not cause any variation in thickness of produced slivers, and the thickness variation of ingoing lap is precisely drafted and it appears on the sliver after a certain time (about 35 seconds in this measurement), as the ingoing fibers need this time interval to pass through the carding engine.

(Received 9, 8. 1954)

\section{1. 緒 言}

一般に紡緽工場の運轉に祭して各工櫫において供給 と添り出しの相互の筷係老明確にすることなく，常龍 的に各工程に均齊な單位長當りの重揘を要求してきた 傾向がある。るらろて均候な製品を得るため各工程に

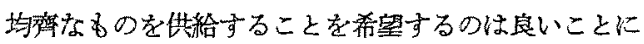

は㟟いないが，供給のさらと总り出しのむらとの相互 關係，むらの限度，さらにむら登生の機棈を知ること なく，漠然と均率を肴基するのは品質管理上意趶のな いことでる。特にカードのもら登生の模樣は湜打綿 譏揚りのラップのむら技よび脚綿機以降の工程を考え る上にぜひとも必要であるので，おれわれはカードに

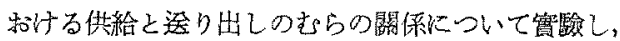


岁わさてカードに括ける繊維の移動の狀況を考えた。

\section{2. 實驗方法}

\section{A. 定自供給}

カードのむらについて樞踰するに當り第一に間題に なるのは常に一定䁷ずつ供給するには如何にすれい゙良 いかといらことでる。われわれは種々な方法につい

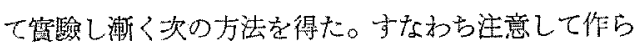
れたカード提りのスライバをカードの壆幅全鳢に坄均 に食い这双方向に並べる。もしカードのドラフトが 100 とすれば100本のスライパをダブリングして供給 することによつて，最初供給したラップと同じ緎維䑁 巷供給することができ，100本をダブリングすること に上つて供絽のむらは平均されるるのと思わ机る。 れわれはこの倛給方式を定買供給之考兑，この上に人

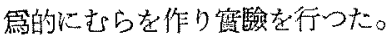

\section{B. 供給むら}

希望寸る供紛むらを作るには前記の定量供給スライ 、゙群の上に同じスライパの希望なる本数を，おる長さ

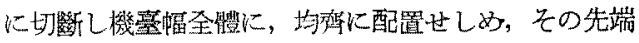

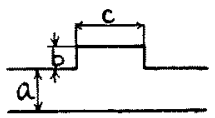

Fig. 1 がー㖟にフィート・・ーラに 共い込ま机るようにすること によつて，模型的むらを定量 供給上に作つた。第 1 圆で $a$ は定量供給量， $b$ はむらら䯩 さ（aに對する制合で表わす），cはむらの長さを示す。 なおこのむらは刞樋工程のラップのむらと異なり人䈑 的であるから直線的，階段的で京り，機垔幅に㖶して

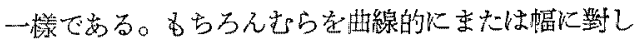
て部分的と作ることも可能であるが，われわれは供給

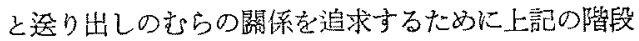
的なむらによつて筑驗した。

\section{C，迤り出しスライバのむら測定}

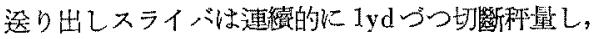
これを重睹（gr）または定量供給の場合のスライバの

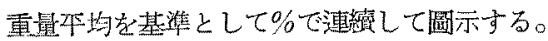

\section{D. カードについて}

本實驗に使用したカードは綿紡式フラットカードで あつて，トップは106本，そ狆を1本置きにトップ針 布を偯つだので，䛨紐は次の道り。

$$
\begin{aligned}
& \text { 回轉数 シリンダ } 174 \mathrm{r} / \mathrm{m} \\
& \text { ドッファー } \quad 6.8 \mathrm{r} / \mathrm{m} \\
& \text { テーカーインローラ } 204 \mathrm{r} / \mathrm{m}
\end{aligned}
$$

カレンダ・ローラの逞り出乙長 $0.354 \mathrm{yd} / \mathrm{sec}$

$$
\begin{aligned}
& \text { ドラフト } 98.85 \\
& \text { ゲージテーカーイン〜シリンダ } 10^{\prime \prime} / 1,000 \\
& \text { シリンダ 〜フラット } 11^{\prime \prime} / 1,000 \\
& \text { シリンダ 〜ドッファー 5" } 51,000
\end{aligned}
$$

使用緎維はビスコース・スフ, 港縮 $3 \mathrm{~d} \times 3^{\prime \prime}$

琶羷は並揣除後約 30 分を絓過して, 供給とり出 しとが定常狀熊となつたと格えられる時行つた。

\section{3. 實驗ならびにその結果}

\section{A. 普通の供給および定量供給の送り出しむら}

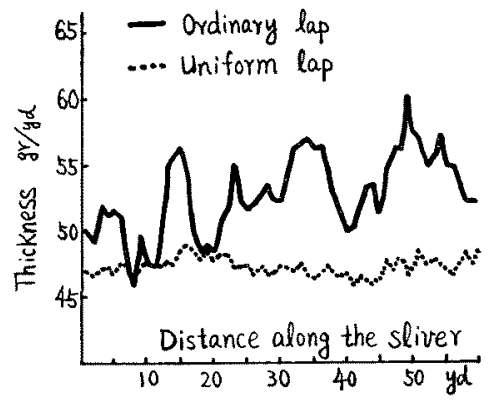

Fig. 2

第 2 圆に普通作業のラップ $\left(12^{2 z} / \mathrm{yd}\right)$ 供給の場合と 定量供給の場合の送り出しのもらを示す。定量供給は $48.3 \mathrm{gr} / \mathrm{yd}$ のスライハ 100 本 $(110 z / \mathrm{yd}$ のラップに相 當する)を使用，各 60 回測定した。鲜に括いて普通

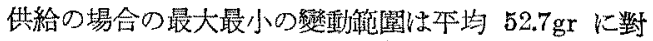
して 15gr であり，變動係努 $\% / \bar{X}=0.057$ ，定量供給

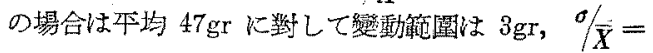
0.010 なお定量供給の选り出しスライバをさらに 100

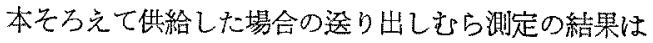

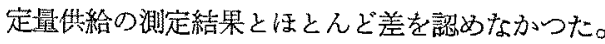

以上の結果からカードが作るさらは非常に小さいこ

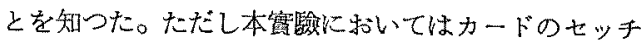
ングを完全にする必要があり，例亲ばテーカーインロ

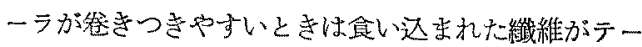
カーインローラに蓄党られ，艺れが特々迲り出されて スライバ中に大きなむらを作ることがある。なたゲー

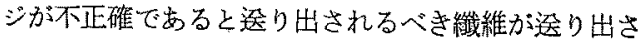
れす゚に回轉して不正確に送り出されて定昷供給の昜合 でもさらを生ずることを認める。

\section{B. b を题えた場合}

第3 圆に b $+20 \%,+40 \%,+60 \%$, 第 4 圖に 


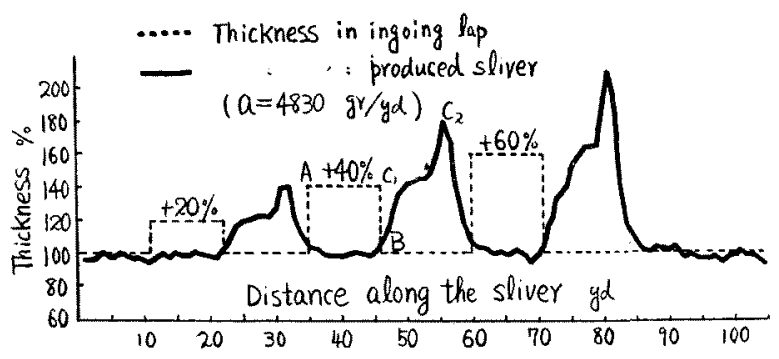

Fig. 3

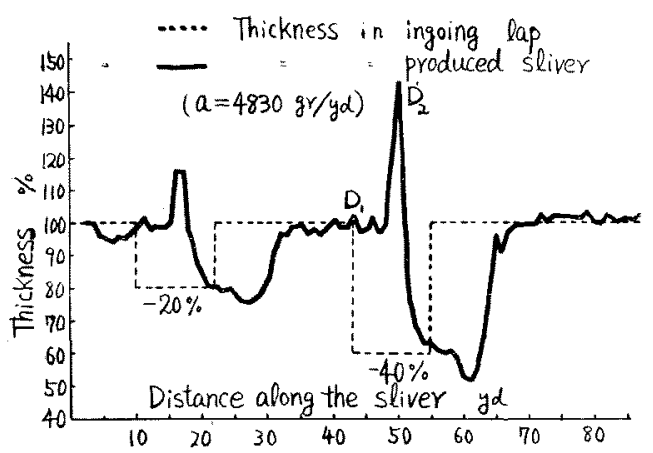

Fig. 4

$-20 \% ，-40 \%$ とした場合を示与。(定量供給量は前 記 100 本を基準としこれを $100 \%$ とする。） $c=44^{\prime 。}$ 。回 に机いてスライバの1點が深り出されると同時刻に， フィード・ローラの直下に食い込まれる緎維量を點線 で示し，同じ橫座標に記入した。すなかち第3圆にお いて供給むらの先端 A がフィード・ローラの直下に 入つた時から計つてスライバが約 $12 \mathrm{yd}$ 选り出された

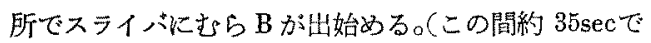
この點に閣しては後報に述べる。)故に橫軸性間を示 すすのとる考克られる。この場合はカレンダ・ローラ の送り出し夤度から 1 目盛 (1yd) は2.8sec 示す。 第3圖において逶り出し曲線がすらの終りC2に，第 4 圆では（一）もらの始め D2にピークを示している。

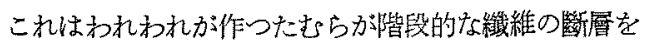
持つているため, 織維淮宁の方向から考えて高から低 に移る斯層をなす瀻維末端 C,D がフィード・ローラ

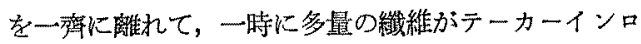
一ラに染り込まれる閣係上ビークを示するのと思う。 (この點から考皇て，フィードローラが1對のローラ でなくデイシェブレート型であることは意味のあるこ
とであり，むらのピーク防止のためにもデ イシュプレートの形を考える必姴を認め 尚。)

さらにこれを確かめるために第5圂に三 段囱になつたをらを供給して見た。すなか b $c_{1}=2^{\prime \prime}, b_{1}=60 \%, c_{2}=3^{\prime \prime}, b_{2}=40 \%, c_{3}$ $=4^{\prime \prime}, b_{3}=20 \%, こ の$ 結果は祻以見るよ 5 に3カ所にピークを示した。

以上の䨘驗から(十)及び（一)のむら が正確にドラフトされて一定時間後に邆り

出されることを知つた。

\section{C. a を紸えた場合}

第 6 圖にaを以上の蹇 騟の $50 \%$ としてbを+ $20 \%,+40 \%,+60 \%, \mathrm{c}$ =4"とした場合を，第 7 鱿にaを $140 \%$ これは

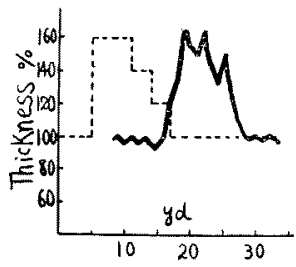

Fig. 5
$15.4^{02} / \mathrm{yd}$ のラップ供給に相賞する) にして $\mathrm{b}=+20$ $\%,+40 \%, c=4 "$ の場合を示す。これらを第 3 圆に 比較すればさら發生の形は、による差をなつたく認め

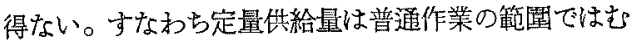
ら發生には影靘しない。

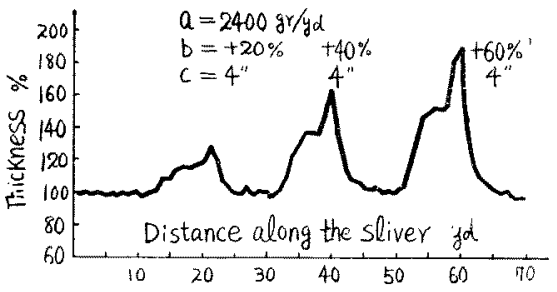

Fig. 6

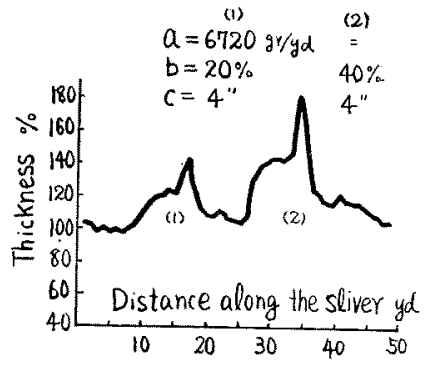

Fig. 7

\section{Cを摔えた場合}

第 8 㽞化 $c=8^{\prime \prime}, \mathrm{b}=+20 \%$ 娄示す。先 $\sigma \mathrm{c}=4^{\prime \prime}$ 
の場合に比し这り出しむらの長さがcに汪佂比例して いる铝を認める。

\section{E．供給むら構成する識維の移行}

定量供給スライバ群に白色瀻維を使用し，これに染 色した纖維のむら（染色䩪燥㣪カードを通してスライ

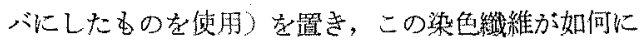

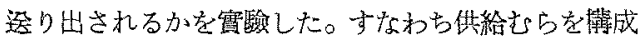
する纖維と运り出されるむらを秧成する纖維との關係

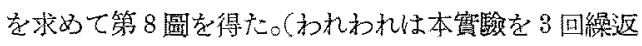

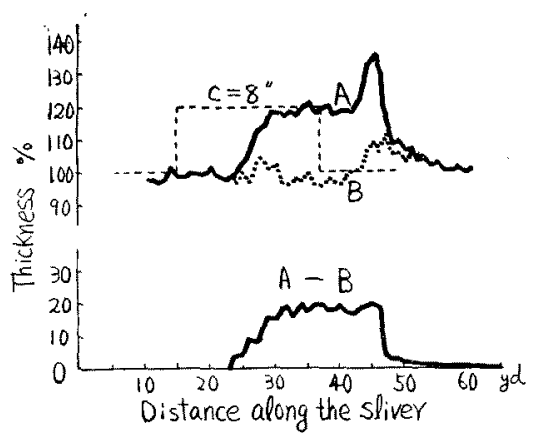

Fig. 8

したがまつたく同一の結果を得た。䢪り出しスライバ DIyd長資料をよく開綿湿綿し，比色心よつて定量共

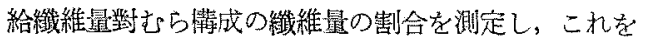
㖥の下部に示す。の割合から出しスライバ中の 定量供給瀻維量 (白色蟣維最) を算出すればB曲線之

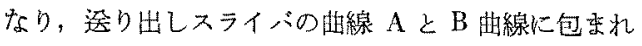

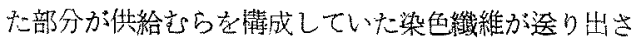
れた圔を示す。

以上の實驗より次の結諭を得る。すなわり普通力一 ドに供給されるラップの重胆の範葍では, 供給のむら

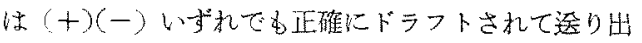
される。そして供給のむらを構成していた織維は这り

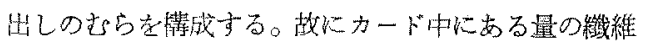
が蓞克られてから，供給されただけの星が蓄克られた

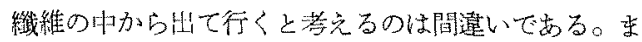

た供給むらを搆成していた瀻維は邆り出しにむらが出

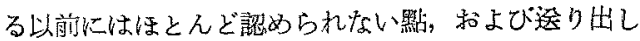

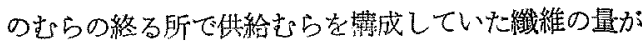

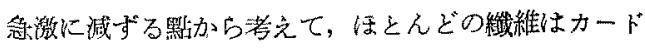
中を規則正しいニースを時間的にも正破に移行与る。

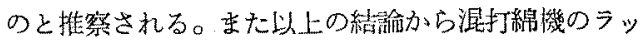
プのむらをカードの送り出しスライ゙゙のむらから推察 することができる。しかしこの場合特に注意すべきは 使用カードがむらを作るような不備の黳がないことで 岕る。これ定量供給を行いその送り出しスライパの むらを測定してみれば制明する。すなわらこの方法は カードの性能試驗法とる考它られる。

\section{4. 總 括}

綿紡式フラットカードに执いて, 供給と送り出しと の量的, 質的關係を明確にするため，定量供給方式を 洘光，この上に模型的な斯給むらを作り，これによっ て送り出しのむらを譪測した。

1. カード揚りのスライバを引きそら支て供給する ことによつて定量供給と洘觉ることができる。

2.この定最低給によつて完全保保全されたカード はむらを作らないと若えて良い。逆にむらを作る場合 はセッチングが良くないと考える。

3. 定量供給スライバ群上に希鼠与る量のスライバ を置くことによつて希望するむらを作ることができる。

4.このさらを供給した結果, 普通作業狀態の供給 量炕いてはをのもらは正確にドラフトされて一定時 間後に送り出されることが制明した。

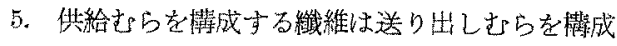
し, 送り出しむらの前後には非常に微量である。

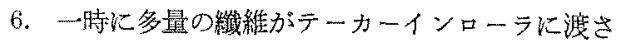
れるときは送り出しむらにピークを示す。

7. 食い込みと送り出しとの時間的ずれから䋍維の 移行を追求することができる。

本研究を獬援助下さつた柬京工業大學㸚授石川音一, 田畑助手飞深媩劣る。 